\title{
Occurrence of the Endangered Antillean manatee Trichechus manatus manatus in a marine protected area, Isla de la Juventud, Cuba
}

\author{
Anmari Alvarez-Alemán, Jorge A. Angulo-Valdés, Eddy García Alfonso \\ James A. Powell and Cynthia R. Taylor
}

\begin{abstract}
The Antillean manatee Trichechus manatus manatus is categorized as Endangered on the IUCN Red List but little is known about the status of the species in Cuba. Marine protected areas can contribute to manatee conservation in Cuba but the effectiveness of these areas may be jeopardized by a lack of information regarding appropriate design and management. We developed an index of manatee occurrence in the Fauna Refuge Ciénaga de Lanier, Isla de la Juventud, to assess patterns of manatee use in the reserve. We completed 26 field trips during November 2007October 2013, with a total of 147 survey days. Manatee presence was detected on $47 \%$ of survey days and in $96 \%$ of field trips; 133 individuals were recorded in 93 sightings. The index of manatee occurrence varied between trips, suggesting a discontinuous use of the area. The mean group size was 1.4 individuals (range 1-5), and calves were observed in $13 \%$ of sightings. Observations of manatee behaviour, occurrence and habitat characteristics indicate the importance of the study area as a resting place, refuge and source of fresh water. We recommend that manatee protection be strengthened to avoid human-related mortality and to ensure that the habitats that provide critical resources are given special consideration in future management plans.
\end{abstract}

Keywords Antillean manatee, conservation, Cuba, habitat, index of occurrence, marine protected area, Trichechus manatus manatus

\section{Introduction}

7 he Antillean manatee Trichechus manatus manatus is 1 categorized as Endangered on the IUCN Red List (Self-Sullivan \& Mignucci-Giannoni, 2008) and faces a variety of threats from human activities and natural events.

Anmari Alvarez-Alemán* (Corresponding author) and Jorge A. Angulo-Valdés Centro de Investigaciones Marinas, Universidad de la Habana, Calle 16 \# $114 \mathrm{e} /$ 1ra y 3ra, Playa, Havana, Cuba. E-mail anmarialvarez@yahoo.com

Eddy García Alfonso Empresa Nacional para la Protección de Flora y Fauna, Villa Clara, Cuba

James A. Powell and Cynthia R. Taylor Sea to Shore Alliance, Sarasota, USA

${ }^{*}$ Current address: School of Natural Resources and Environment, University of Florida, Gainesville, Florida, FL 32611, USA

Received 3 June 2015. Revision requested 21 July 2015.

Accepted 16 September 2015. First published online 29 March 2016.
Although manatees have protected status in most of their range countries, enforcement of regulations and scarcity of information continue to be a challenge to their conservation (Marsh \& Lefebvre, 1994). The creation of protected areas is an important tool for manatee conservation; however, the effectiveness of these areas is often questioned. Many are considered to be paper parks (i.e. protected areas that exist in name only), with no measurable impact on conservation (Marsh \& Morales-Vela, 2014). Important aspects that must be taken into account when designing and managing effective protected areas for manatees are the identification of critical habitats, such as breeding and feeding areas, and the distribution and magnitude of threats (Marsh \& Morales-Vela, 2014).

A group of marine protected areas has been established in Cuba as part of a national system of protected areas. Management plans for some of these marine protected areas include manatees as a key species for conservation (Centro Nacional de Áreas Protegidas, 2013). However, there are not adequate data to understand and evaluate the effectiveness of these protected areas and their contribution to the protection and survival of this species. Some marine protected areas and their contribution in Cuba are not officially approved, lack administration, and have poorly implemented enforcement, which suggests they may not be effective in supporting manatee conservation. Our study area, Ciénaga de Lanier, is categorized as a Fauna Refuge in the Cuban national system of protected areas. One of the management goals is to protect the manatee population; however, no information is available regarding how manatees use this area. In addition it is unclear whether critical habitats for this species are included within the boundaries of the marine protected area. Thus our aim was to determine how this habitat was being used by the manatees, and to study the influence of abiotic and anthropogenic factors on manatee occurrence.

\section{Study area}

The study was conducted in Ciénaga de Lanier, a RAMSAR site (Wetland of International Importance) and Fauna Refuge (Fig. 1). The area has not yet been legally designated but is recognized nationally within the Cuban system of protected areas (Centro Nacional de Áreas Protegidas, 2013). It occupies a total of 24,118 ha, with a marine area of c. 7,403 ha (Centro Nacional de Áreas Protegidas, 2013). 


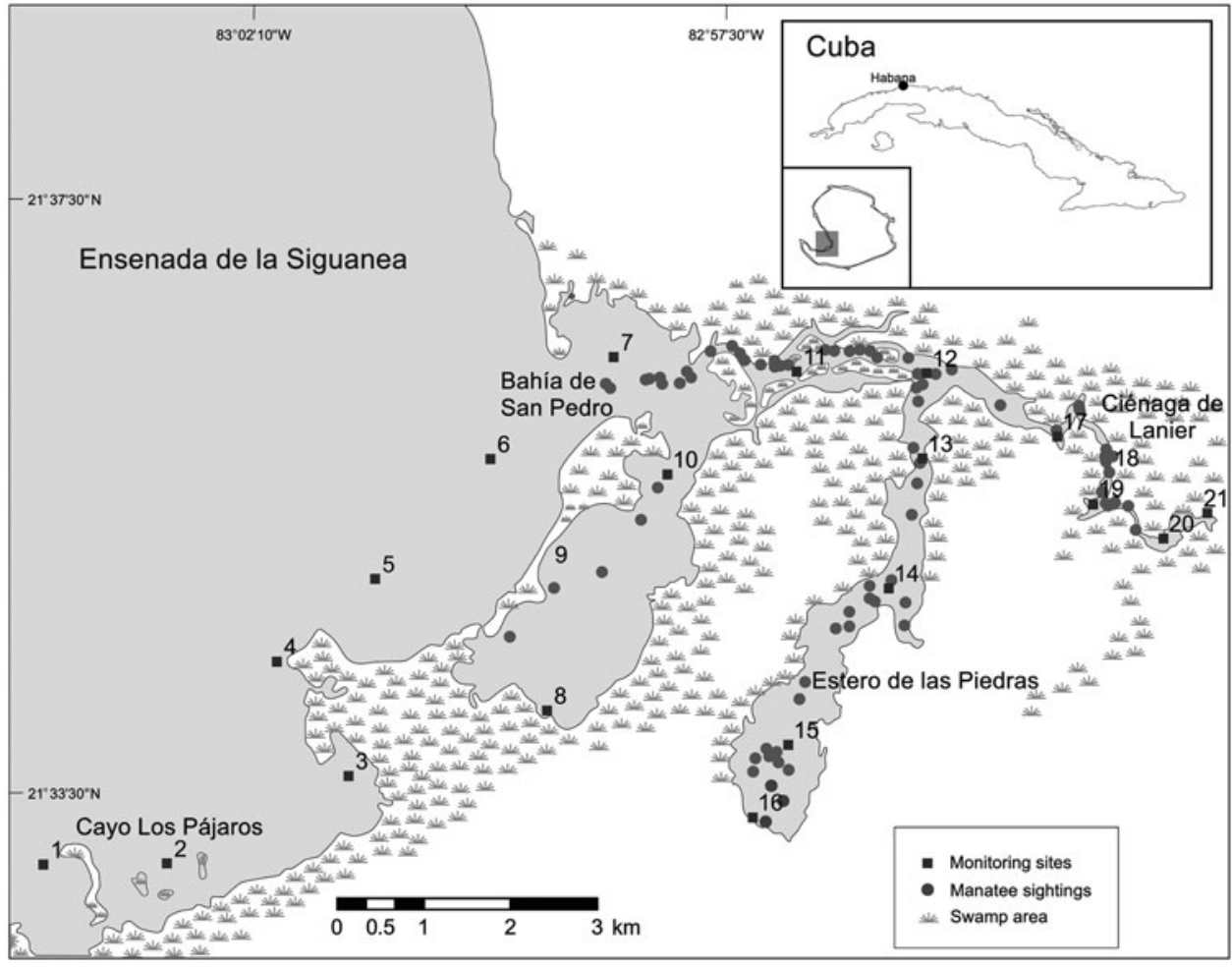

FIg. 1 Ciénaga de Lanier marine protected area (shaded area in inset), Isla de la Juventud, Cuba, where monitoring surveys were carried out during 2007-2013 to assess patterns of use by the Antillean manatee Trichechus manatus manatus.
The study area is located in the western drainage of a wetland ecosystem that extends from the west to the east of Isla de la Juventud and encompasses several coastal lagoons and mangrove creeks (Fig. 1). The dry season is during November-March and the wet season during April-October. During the wet season freshwater outflow from land is significant, thus increasing the availability of fresh water in the immediate vicinity of this wetland (Instituto Cubano de Hidrografía, 1989).

\section{Methods}

\section{Boat-based surveys}

We conducted boat surveys to search for and record the presence of manatees (Smethurst \& Nietschmann, 1999; Castelblanco-Martínez et al., 2009). Lagoon systems, mangrove creeks and coastlines were surveyed at a speed of 2-9 knots, with at least four observers constantly searching for manatees and floating faecal material. Faeces were collected and recorded as indirect evidence of manatee presence.

For each sighting we recorded the location (using a global positioning system), time, number of individuals, presence of calves, behaviour, temperature and salinity of bottom and surface waters, depth and sea state (Beaufort scale). Multiple individuals were defined as a group when the distances between them were similar to the mean length of an individual (c. 2.7 $\mathrm{m}$; Auil, 2004; Reep \& Bonde, 2006). Individuals smaller than half the size of an adult and observed in close proximity to an adult, usually displaying synchronized breathing, were recorded as calves (Irvine \& Campbell, 1978).

Manatee faecal samples often float at the surface and can remain identifiable for up to 2 days (Hartman, 1979), depending on the weather, sea conditions, salinity and the presence of other animals that might feed on them. The complexity of the shoreline in the study area (e.g. many creeks and lagoons) probably limits drift movement of faecal samples, and therefore we used the presence of faecal samples as an indicator of manatee use of the area in cases where they were not associated directly with manatee sightings. The numbers of manatee sightings $(s)$ and faecal samples $(f)$ were used as an index of manatee occurrence $(\mathrm{IMO}=(s+f)$ /survey time $)$ and as an indicator of the use of the study area by manatees. We also calculated this index for the number of faecal samples $\left(\mathrm{IMO}_{f}=f /\right.$ survey time) and the number of sightings $\left(\mathrm{IMO}_{s}=s\right.$ /survey time) separately.

We categorized our observations of manatee behaviour as follows: resting (no movement), feeding (inferred if manatees were observed swimming in circles in an area with abundant vegetation, and sediment was detected in the water column), socialization (a group of manatees splashing, swimming in circles or exhibiting friction between individuals), and directed movement (Irvine, 1982). This last category included manatees that were observed swimming or showing a response to an approaching boat (Nowacek et al., 2004). This type of evasive behaviour was identified by a noticeable increase in swimming speed, and changes in orientation and in the distance between individuals (Nowacek et al., 2004). 
Evaluation of temperature, salinity, and human impact

Twenty-one monitoring sites were pre-established to measure water temperature and salinity at surface and bottom, ambient temperature and wind speed $\left(\mathrm{km} \mathrm{h}^{-1}\right)$. Temperature and salinity were measured $\left( \pm 0.2^{\circ} \mathrm{C}\right.$ and $\pm 0.2 \%$, respectively) using an EcoSense instrument (YSI Inc., Yellow Springs, USA). A Kestrel gauge (KestrelMeters.com, Birmingham, USA) was used to measure wind speed and ambient temperature $\left( \pm 0.1 \mathrm{~km} \mathrm{~h}^{-1}\right.$ and $\pm 1^{\circ} \mathrm{C}$, respectively). Wind speed was used in an assessment of the sea state on each trip, according to the Beaufort scale (1, ripples with appearance of scales; 2, small wavelets, crests of glassy appearance, not breaking; 3, large wavelets, crests begin to break, scattered whitecaps; 4, small waves, becoming longer, numerous whitecaps). Salinity records were used to assess the availability of fresh water at monitoring sites 18-21 because these were located inland and were influenced by an adjoining swamp (Fig. 1). Rainfall data were obtained from the Meteorological Institute at Isla de la Juventud.

We recorded the presence of boats in the area and used this as an indicator of human use. When possible we also recorded the types of fishing gear used, as well as the number of people on board. The human impact was assessed as the number of boat encounters per day.

\section{Data analysis}

We tested data for normality, and compared survey effort (survey time) over the study period. We used the KruskalWallis ANOVA and median test for surveyed years, and the Mann-Whitney $U$ test between seasons. A Spearman rank order correlation was used to determine the influence of the abiotic variables and human presence on the index of manatee occurrence during wet and dry seasons separately. We also compared the index of manatee occurrence among years using a Kruskal-Wallis ANOVA.

\section{Results}

Survey effort, sightings and index of manatee occurrence

We completed 26 trips, comprising a total of 147 boat survey days, during November 2007-October 2013. The survey time effort $\left(\mathrm{H}=5.6, \mathrm{P}=0.46 ; \mathrm{X}^{2}=2.5, \mathrm{P}=0.86\right)$ remained consistent over the years. There was a significant difference in the survey time effort within each year ( $U=9, \mathrm{P}=0.0009$ ), with more data recorded during the wet season.

We covered a total of 1,741 nautical miles in 467 hours over 148 days (Table 1). We recorded manatee presence on $47 \%$ of survey days and in $96 \%$ of trips. Up to 133 manatees were recorded during 93 sightings. Our survey methods did not facilitate identification of individuals, and therefore absolute abundance estimates are not available. We counted at least five individuals in July 2009: a mother and calf and a group of three adults. Eight individuals were observed in one day in January 2010. They displayed synchronized surfacing, ensuring that we did not count the same individual twice, and were separated by $>100 \mathrm{~m}$.

There were significant differences among the studied years in the index of manatee occurrence based on sightings and faecal samples, as well as that based only on sightings $(\mathrm{H}=14.16, \mathrm{P}=0.03$, and $\mathrm{H}=13.79, \mathrm{P}=0.03$, respectively). Fig. 2 shows an increasing trend during 2007-2013. The index of manatee occurrence based only on faecal samples remained stable $(\mathrm{H}=6.33, \mathrm{P}=0.4)$.

Two prominent peaks in the index were observed, in January 2009 and January 2010, which corresponded with a decrease in the ambient temperature as a result of cold fronts (Fig. 3). The highest value (1.30) occurred during the dry season in January 2010, when the lowest air temperatures were recorded $\left(15^{\circ} \mathrm{C}\right)$ and there was a higher number of sightings (13 sightings, 20 individuals). Manatees were detected in waters up to $5^{\circ} \mathrm{C}$ warmer than the mean nearcoastal water temperature, which was c. $18^{\circ} \mathrm{C}$. These warmer waters may be used by manatees as a thermal refuge during cooler weather.

Variations in the index of manatee occurrence were observed during the wet season, associated with the availability of fresh water (lower salinity) and sheltered sea conditions. No correlation with environmental variables was detected during the dry season (Table 2).

\section{Temperature, salinity, and human impact}

Fresh water was available in the superficial layer of inland waters. The mean surface salinity during the study period was $6.6 \mathrm{ppm}$, and the mean surface salinity during the dry and wet seasons was 15.8 and $4.8 \mathrm{ppm}$, respectively. The salinity of $<10 \mathrm{ppm}$ recorded during some of the trips highlights the importance of the area in providing a freshwater resource (Table 1).

Water (surface and bottom) and ambient temperature declined during the dry season (November-March; Table 1). The minimum surface and bottom water temperatures recorded were 19 and $22^{\circ} \mathrm{C}$, respectively. The maximum mean temperature recorded was $31^{\circ} \mathrm{C}$. Some areas showed a temperature inverted halocline (Stith et al., 2011), such as is commonly used by resting manatees in Florida for passive thermoregulation. At sites 17-21, which were close to the swamp, the temperature of the bottom water exceeded the surface temperature by up to $5.1^{\circ} \mathrm{C}$.

We encountered 55 boats during the study, representing 0.5 boats per day. Of these, $71 \%$ were non-motorized or rustic boats (made from palm trees). Tuna, fin-fish and lobster fishing boats comprised $23.6 \%$ of the boats recorded. 
TABLE 1 Survey effort, Antillean manatee Trichechus manatus manatus information (no. of sightings, percentage of sightings with calves, no. of individuals, no. of faecal samples) and abiotic variables (air temperature, water temperature at surface and bottom, salinity at surface and bottom, rainfall, sea state) recorded during 26 trips to the Ciénaga de Lanier marine protected area, Isla de la Juventud, Cuba (Fig. 1), during 2007-2013. Mean salinity was recorded only at sites 18-21 (Fig. 1), to assess the presence and fluctuation of fresh water at the sites close to the swamp; mean temperature was recorded at all monitoring sites. Blank cells indicate missing data.

\begin{tabular}{|c|c|c|c|c|c|c|c|c|c|c|c|c|c|c|}
\hline \multirow[b]{2}{*}{ Year } & \multirow[b]{2}{*}{ Month } & \multicolumn{2}{|c|}{ Survey effort } & \multicolumn{4}{|c|}{ Manatee information } & \multirow[b]{2}{*}{ Air temp. $\left({ }^{\circ} \mathrm{C}\right)$} & \multicolumn{2}{|c|}{ Water temp. $\left({ }^{\circ} \mathrm{C}\right)$} & \multicolumn{2}{|c|}{ Salinity (\%) } & \multirow[b]{2}{*}{ Rain (mm) } & \multirow{2}{*}{$\begin{array}{l}\text { Sea state } \\
\text { (Beaufort } \\
\text { scale) }\end{array}$} \\
\hline & & $\begin{array}{l}\text { (nautical } \\
\text { miles) }\end{array}$ & Time (h) & Sightings & $\begin{array}{l}\% \text { sightings } \\
\text { with calf }\end{array}$ & Individuals & $\begin{array}{l}\text { Faecal } \\
\text { samples }\end{array}$ & & Surface & Bottom & Surface & Bottom & & \\
\hline 2007 & Nov. & 50 & 16 & 1 & 0 & 3 & 1 & & 26 & & & & 0 & \\
\hline 2007 & Dec. & 34 & 8.3 & 1 & 0 & 1 & 0 & & & & 5.0 & & 64 & \\
\hline 2008 & Jan. & 33 & 9.7 & 1 & 0 & 1 & 0 & & 22.9 & 23.7 & 5.5 & 33.0 & 3.3 & \\
\hline 2008 & May & 72 & 13.8 & 3 & 0 & 3 & 0 & 29.7 & 30.2 & 29.9 & 32.3 & 33.5 & 61.6 & 3 \\
\hline 2008 & June & 46 & 14.8 & 0 & & 0 & 0 & 28.4 & 29.6 & 29.2 & 31.0 & 33.3 & 117 & 3 \\
\hline 2008 & Dec. & 28 & 5.4 & 1 & 0 & 1 & 0 & 25.4 & 24.2 & 25.1 & 8.4 & 32.1 & 11.0 & 4 \\
\hline 2009 & Jan. & 21 & 3.7 & 2 & 0 & 4 & 1 & & & & & & 12.7 & \\
\hline 2009 & May & 48 & 8.7 & 0 & & 0 & 1 & & 29.5 & 29.4 & 35.0 & 35.2 & 144 & 3 \\
\hline 2009 & June & 39 & 13.1 & 1 & 0 & 1 & 0 & 28.7 & 30.1 & 30.4 & 29.9 & 30.8 & 281 & 2 \\
\hline 2009 & July & 112 & 30.0 & 5 & 60 & 13 & 1 & 31.7 & 31.3 & 31.4 & 10.4 & 31.6 & 120 & 2 \\
\hline 2009 & Aug. & 108 & 26.0 & 4 & 0 & 4 & 3 & 31.7 & 31.0 & 31.1 & 14.4 & 30.4 & 69.0 & 2 \\
\hline 2010 & Jan. & 38 & 10.0 & 13 & 0 & 20 & 0 & 16.9 & 19.6 & 22.2 & 8.6 & 33.2 & 25.6 & 4 \\
\hline 2010 & June & 62 & 20.4 & 5 & 0 & 5 & 0 & 32.6 & 30.1 & 30.6 & 26.3 & 32.7 & 232 & 3 \\
\hline 2010 & July & 185 & 59.2 & 14 & 0 & 15 & 1 & 32.4 & 30.7 & 30.7 & 4.1 & 21.9 & 141 & 1 \\
\hline 2010 & Aug. & 68 & 20.5 & 8 & 12.5 & 9 & 1 & 26.7 & 31.2 & 31.6 & 2.5 & 17.7 & 218 & 1 \\
\hline 2011 & Feb. & 44 & 11.2 & 2 & 0 & 2 & 0 & 34.6 & 27.7 & 26.0 & 13.2 & 34.0 & 3.0 & 1 \\
\hline 2011 & July & 250 & 69.4 & 4 & 0 & 8 & 4 & 32.3 & 30.9 & 30.6 & 8.4 & 22.6 & 547 & 3 \\
\hline 2011 & Aug. & 78 & 22.8 & 0 & & 0 & 3 & 33.6 & 30.6 & 30.5 & 2.4 & 14.8 & 391 & 2 \\
\hline 2012 & Feb. & 44.6 & 11 & 1 & 0 & 1 & 0 & 27.4 & 25.8 & 26.6 & 27.1 & 33.2 & 62.8 & 3 \\
\hline 2012 & June-July & 119 & 31 & 7 & 33.3 & 10 & 4 & 32.4 & 30.1 & 30.2 & 2.3 & 15.7 & 272 & 2 \\
\hline 2012 & Aug. & 46 & 14 & 2 & 100 & 6 & 1 & 31.1 & 29.7 & 30.6 & 4.1 & 28.9 & 131 & 2 \\
\hline 2012 & Nov. & 27 & 7.5 & 3 & 33.3 & 3 & 0 & 26.7 & 24.6 & 25.7 & 7.8 & 18.2 & 5.3 & 3 \\
\hline 2013 & Mar. & 21 & 4 & 3 & 66.7 & 7 & 0 & 27.6 & 24.9 & 24.5 & 32.3 & 33.3 & 48.3 & 2 \\
\hline 2013 & June & 19 & 4 & 1 & 0 & 1 & 3 & 30.7 & 29.3 & 29.3 & 1.5 & 7.6 & 587 & 2 \\
\hline 2013 & July & 123 & 29 & 7 & 14.3 & 11 & 2 & 32.0 & 29.7 & 29.5 & 1.4 & 4.2 & 255 & 2 \\
\hline 2013 & Oct. & 25 & 7 & 4 & 0 & 4 & 0 & 26.0 & 27.7 & 28.4 & 1.5 & 17.5 & 214 & \\
\hline
\end{tabular}




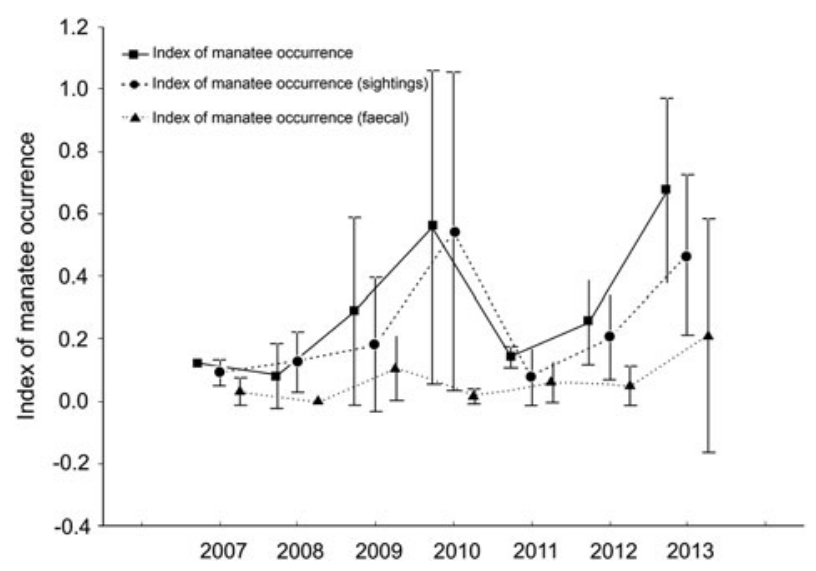

FIG. 2 Yearly index of manatee occurrence, with standard deviation, based on faecal samples and manatee sightings combined, manatee sightings only, and faecal samples only, for the Ciénaga de Lanier marine protected area, Isla de la Juventud, Cuba (Fig. 1), during 2007-2013.

\section{Group size and behaviour}

Solitary individuals comprised $74 \%$ of all sightings, and the majority of pairs comprised a mother and a calf. The mean group size for all surveys was 1.4 individuals (range 1-5). Calves were observed in $13 \%$ of sightings. Mother/calf pairs were observed during seven of the 26 survey trips, but during the last 2 years of surveys mother/calf pairs were observed during $63 \%$ of the trips (Table 1 ).

In $82 \%$ of sightings manatees were observed swimming or responding to the survey boat. The latter category was assigned when the manatees displayed behaviours such as swimming into deep areas; a prolonged surface breath followed by a prolonged dive; fleeing the boat; a rapid increase in swimming speed, using the tail and causing a body wake or water splash; and separation and dispersal of manatee groups.

Feeding and resting behaviour was observed in 10 and $9 \%$ of sightings, respectively. Feeding was observed in areas dominated by Thalassia testudinum, with some patches of Halodule wrightii. Resting manatees were detected in one of the widest creeks in the area, near several small springs (in proximity to Site 16; Fig. 1).

\section{Discussion}

\section{Habitat suitability}

Availability of fresh water is important for manatees (Marsh et al., 2011). The reliable availability of fresh water and scarcity of periods when the water temperature was $<20^{\circ} \mathrm{C}$ indicated suitable habitats for manatees in the study area. Habitats with a temperature inverted halocline, as recorded in the study area, can provide a warm salty bottom as a refuge for manatees during cold weather (Stith et al., 2011).
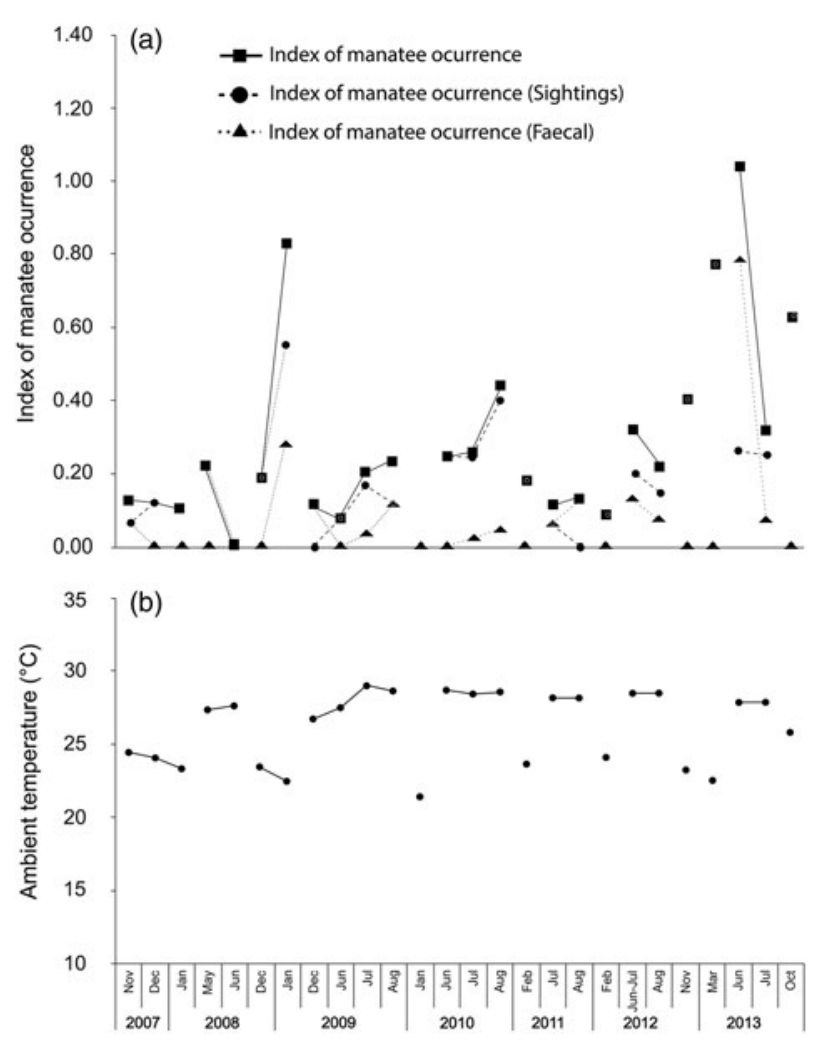

FIG. 3 (a) Index of manatee occurrence based on faecal samples and manatee sightings combined, manatee sightings only, and faecal samples only and (b) monthly mean ambient temperature recorded in the Ciénaga de Lanier marine protected area, Isla de la Juventud, Cuba (Fig. 1), during 2007-2013. The temperature data were obtained from the Meteorological Institute of Isla de la Juventud.

The incidence of boats in our study area (0.5 per day) differed significantly from that recorded in Tortuguero National Park, Costa Rica, for instance, where 669 boats were recorded in a period of 36 hours (Smethurst \& Nietschmann, 1999). The boats we observed were used to catch fish for consumption (especially rustic boats used by local people) or bait for fishing, and were anchored at night and during bad weather. There is not a major commercial fishery in the area. There was no evidence that these boats pose a significant threat of accidental death as a result of collision or entanglement in fishing gear. However, anecdotal reports suggest that fishers may take manatees opportunistically as a source of animal protein. Human presence in the study area was low during the surveys, and therefore we conclude that the risk of human-related mortality is probably minimal. Nonetheless, poaching activities have been reported, and the remains of three manatee carcasses were found during the 6-year study period. The presence of poachers is poorly regulated because of the absence of a local administration office in the protected area and the lack of enforcement of existing regulations, and thus illegal hunting of manatees continues. 
TABLE 2 Spearman rank order correlation $(R)$ between the index of manatee occurrence and the variables evaluated during 26 survey trips in the Ciénaga de Lanier marine protected area, Isla de la Juventud, Cuba (Fig. 1), in wet and dry seasons during 20072013. Correlations in bold are significant at $\mathrm{P}>0.05$.

\begin{tabular}{|c|c|c|c|c|}
\hline \multirow[b]{2}{*}{ Variables } & \multicolumn{2}{|c|}{ Wet season } & \multicolumn{2}{|c|}{ Dry season } \\
\hline & $\mathrm{R}$ & $\begin{array}{l}\text { No. of } \\
\text { trips }\end{array}$ & $\mathrm{R}$ & $\begin{array}{l}\text { No. of } \\
\text { trips }\end{array}$ \\
\hline Air temperature & 0.08 & 14 & -0.17 & 7 \\
\hline Surface temperature & 0.06 & 15 & -0.03 & 9 \\
\hline Bottom temperature & 0.17 & 15 & -0.29 & 8 \\
\hline Salinity & -0.64 & 15 & 0.10 & 9 \\
\hline Rain & 0.18 & 15 & 0.16 & 11 \\
\hline Sea state (Beaufort scale) & -0.53 & 15 & -0.05 & 6 \\
\hline Human presence & -0.22 & 15 & -0.02 & 11 \\
\hline
\end{tabular}

\section{Manatee occurrence}

The number of sightings and individuals, the index of manatee occurrence recorded during the study period, and the percentage of survey days on which manatee presence was detected indicate that manatees use this area but not continuously. The fluctuating index of manatee occurrence and the lack of correlation between this index and the environmental variables evaluated suggest that the study area may be only a small fraction of the habitat range of the individuals observed. The survey methods, physical characteristics of the area, and evasive behaviour of manatees decreased the detection probability, and are important limitations in assessing the manatee population size in the study area.

In comparison, the number of sightings recorded was higher than in Costa Rica, where Smethurst \& Nietschmann (1999) recorded 29 sightings during 3,500 person hours in 79 surveys days (o.01 sightings per hour) but did not collect faecal material. De Thoisy et al. (2003) recorded only 10 sightings in French Guiana during June 2000-June 2001. In the Orinoco River in Colombia Castelblanco-Martínez et al. (2009) reported a mean of 0.8 manatees per hour during 1,002.5 hours of observation. Manatees in the Orinoco River live permanently in freshwater habitat far from the ocean, and in certain periods of the year they are confined to relatively limited areas (Castelblanco-Martínez et al., 2009). Variations in the index of manatee occurrence suggest that the movement of manatees in and out of our study area is probably a regular occurrence. Food resources such as submerged vegetation can be found throughout Cuba's aquatic habitats (Alcolado, 2006), which supports dispersal of wildlife and wide-ranging habitat use.

The mean index of manatee occurrence per year increased during 2007-2010 and again during 2011-2013. However, as we were unable to identify individual manatees we could not determine whether additional individuals were using the survey area or whether we were observing the same individuals with more regularity. The discontinuous use of the area within and among survey years suggests that only a portion of the key habitats necessary for healthy manatee populations are being protected within this marine protected area. Adjacent habitats, including travel corridors, need to be investigated to determine their importance and possibly extend protection to facilitate manatee conservation.

Strong cold fronts may increase manatee use of this habitat, as observed during the winter survey in January 2010. Temperature as a limiting resource has been described in detail for the Florida manatee Trichechus manatus latirostris, with some authors reporting that this subspecies moves to warmer water when the air temperature drops below $20^{\circ} \mathrm{C}$ (Hartman, 1979; Marsh et al., 2011). Stith et al. (2011) reported that manatees in the Gulf of Mexico shift to areas closer to shore when temperatures drop below $18-20^{\circ} \mathrm{C}$. Manatees are sensitive to small changes in water temperature within this range (Powell, 2002), so even in tropical regions water temperature needs to be evaluated for its potential influence on their movement and behaviour.

We found a significant negative correlation between the index of manatee occurrence and salinity during the wet season, indicating that lower salinity values resulted in increased use of the study area by manatees. Manatee distribution in tropical waters has been described as a function of fresh water availability rather than temperature (Axis-Arroyo et al., 1998; Montoya-Ospina et al., 2001; Auil, 2004; Olivera-Gómez \& Mellink, 2005). We found a significant correlation between sea state and index of manatee occurrence only during the wet season, and it is likely that sea state influences the probability of detecting individuals.

\section{Group size, calves and behaviour}

The observed group sizes were consistent with reports from Belize and Chetumal, Mexico, where most observations were of solitary manatees; however, these areas presented higher variability in group size (Morales-Vela et al., 2000; Auil, 2004). In French Guiana and the Dominican Republic, solitary individuals and small groups are most frequently observed (Belitsky \& Belitsky, 1980; de Thoisy et al., 2003). We did not detect mating herds during our surveys. The maximum number of manatees $(n=5)$ per group was lower than recorded in other studies outside aggregation sites (e.g. eight in Miami, Reynolds, 1981); 11 on the coast of Florida, Miller et al., 1998; 11 in the Dominican Republic, Belitsky \& Belitsky, 1980; 11 in Belize and Chetumal, Morales-Vela et al., 2000; 22 in Belize, Auil, 2004). The mean group size was similar to those 
observed by Auil (2004) and Morales-Vela et al. (2000) in Belize and Chetumal, Mexico $(n=1.7)$, and lower than those reported for Florida $(\mathrm{n}=2.6$, Reynolds, 1981; $\mathrm{n}=2.19$, Miller et al., 1998).

The presence of calves and the resting behaviour observed in the study area may indicate the suitability of these habitats as calving and resting areas, providing protection to mothers and new-born calves. In eastern Florida Kinnaird (1985) found that resting behaviour was most common in stream habitats. It is likely that in our study area manatees travel frequently between resting and feeding sites but we did not identify any pattern of daily movement. The low frequency of observed behaviours may have been biased by the high number of evasions recorded. It is possible that frequent evasive behaviour is a behavioural adaptation to hunting pressure, similar to that observed in Africa (J. Powell \& L. Keith, pers. comms).

\section{Conclusions}

The index of manatee occurrence indicates that manatees use the study area in varying numbers during the dry and wet seasons, but it does not provide abundance estimates. Along with observed behaviours and habitat characteristics it highlights the importance of the study area as a resting place, a passive thermal refuge, a source of fresh water and a possible nursery area. The absence of information on manatee habitat use and numbers throughout Cuba makes it impossible to compare the results of this pilot study with other regions of the country but emphasizes the importance of continued and expanded research on manatees in Cuba. We recommend that manatee protection be strengthened in the study area to avoid increased human-related mortality and to ensure that the habitats and resources critical to manatees (e.g. springs, sheltered creeks, sources of fresh water, feeding areas and thermal refuges) are given special consideration in future management plans.

\section{Acknowledgements}

This study was supported by financial aid from Operation Wallacea, Sea to Shore Alliance, the MacArthur Foundation, the Eppley Foundation and the GEF-UNDPCNAP project Regional approach to the management of the South Archipelagos of Cuba, 2009-2014. We are grateful for the continuous support of Alton College, Queen Elizabeth School, Lancing College and St Benedict's Catholic School. We thank the Unit of Environmental Management of the Ministry of Science, Technology and Environment (UMA-CITMA-Isla de la Juventud), and the National Centre of Protected Areas and the National Enterprise of Flora and Fauna. We thank volunteers Lázaro V. García, Leandro Rodriguez, Eloisa Rojas, and Roamsy Volta for assistance with figures; Adrian Gerhartz for assistance with developing the maps; and Sophia Langthaler and Thomas O'Shea for their edits and comments. Finally, we thank the local fishers for the information and assistance they provided during our study.

\section{References}

Alcolado, P.M. (2006) Diversidad ecológica. Diversidad, utilidad y estado de conservación de los biotopos marinos. In La biodiversidad marina de Cuba (ed. R.C. Madruga), p. 39. Instituto de Oceanología, Ministerio de Ciencia, Tecnología y Medio Ambiente, Havana, Cuba.

Auil, N.E. (2004) Abundance and distribution trends of the West Indian manatee in the coastal zone of Belize: implications for conservation. MSc thesis. Texas A\&M University, College Station, USA.

Axis-Arroyo, J., Morales-Vela, B., Torruco-Gómez, D. \& Vega-Cendejas, M.E. (1998) Variables asociadas con el uso de hábitat del manatí del Caribe (Trichechus manatus), en Quintana Roo, México (Mammalia). Revista de Biología Tropical, 46, 791-803.

Belitsky, D.W. \& Belitsky, C. L. (1980) Distribution and abundance of manatees Trichechus manatus in the Dominican Republic. Biological Conservation, 17, 313-319.

Castelblanco-Martínez, D.N., Bermdez-Romero, A.L., Gómez-Camelo, I.V., Rosas, F.C.W., Trujillo, F. \& ZERDA-OrdoñEz, E. (2009) Seasonality of habitat use, mortality and reproduction of the Vulnerable Antillean manatee Trichechus manatus manatus in the Orinoco River, Colombia: implications for conservation. Oryx, 43, 235-242.

Centro Nacional de Áreas Protegidas (2013) Plan del Sistema Nacional de Áreas Protegidas 2014-2020. Ministerio de Ciencias Tecnología y Medio Ambiente, Havana, Cuba.

de Thoisy, B., Spiegelberger, T., Rousseau, S., Talvy, G., Vogel, I. \& VIÉ, J.-C. (2003) Distribution, habitat, and conservation status of the West Indian manatee Trichechus manatus in French Guiana. Oryx, 37, 431-436.

Hartman, D.S. (1979) Ecology and behavior of the manatee (Trichechus manatus) in Florida. Special Publications of the American Society of Mammalogists, 5, 1-153.

Instituto Cubano de Hidrografía (1989) Derrotero de las costas de Cuba. Región Marítima del Sur. Editorial Científico Técnica, Havana, Cuba.

Irvine, A.B. (1982) West Indian manatee. In Handbook of Census Methods for Terrestrial Vertebrates (ed. D.E. Davis), pp. 241-242. CRC Press, Boca Raton, USA.

Irvine, A.B. \& Campbell, H.W. (1978) Aerial census of the West Indian manatee, Trichechus manatus, in the southeastern United States. Journal of Mammalogy, 59, 613-617.

IUCN (2014) The IUCN Red List of Threatened Species v. 2014.2. Http://www.iucnredlist.org [accessed 17 September 2014].

Kinnaird, M.F. (1985) Aerial census of manatees in northeasten Florida. Biological Conservation, 32, 59-79.

Marsh, H. \& Lefebvre, L.W. (1994) Sirenian status and conservation efforts. Aquatic Mammals, 20, 155-170.

Marsh, H. \& Morales-Vela, B. (2014). Guidelines for developing protected areas for sirenians. In Sirenian Conservation: Issues and Strategies in Developing Countries (eds E. Hines, J.E. Reynolds, L. Aragones, A. Mignucci-Giannoni \& M. Marmontel), pp. 36-46. University Press of Florida, Gainesville, USA. 
Marsh, H., O’Shea, T.J. \& Reynolds, III, J.E. (2011) Ecology and Conservation of the Sirenia: Dugongs and Manatees. Cambridge University Press, New York, USA.

Miller, K.E., Ackerman, B.B., Lefebvre, L.W. \& Clifton, K.B. (1998) An evaluation of strip-transect aerial survey methods for monitoring manatee populations in Florida. Wildlife Society Bulletin, 26, 561-570.

Montoya-Ospina, R.A., Caicedo-Herrera, D. Millán-Sánchez, S.L., Mignucci-Giannoni, A.A. \& Lefebvre, L.W. (2001) Status and distribution of the West Indian manatee, Trichechus manatus manatus, in Colombia. Biological Conservation, 102, 117-129.

Morales-Vela, B., Olivera-Gómez, D., Reynolds, III, J.E. \& Rathiun, G.B. (2000) Distribution and habitat use by manatees (Trichechus manatus) in Belize and Chetumal Bay, Mexico. Biological Conservation, 95, 67-75.

Nowacek, S.M., Wells, R.S., Owen, E.C.G., Speakman, T.R., Flamm, R.O. \& NowaCeK, D.P. (2004) Florida manatees, Trichechus manatus latirostris, respond to approaching vessels. Biological Conservation, 119, 517-523.

Olivera-Gómez, L.D. \& Mellink, E. (2005) Distribution of Antillean manatee (Trichechus m. manatus) as a function of habitat characteristics in Bahía de Chetumal, Mexico. Biological Conservation, 121, 127-133.

Powell, J.A. (2002) Manatees: Natural History and Conservation. Voyageur Press, Vancouver, Canada.

Reep, R.L. \& Bonde, R.K. (2006) The Florida Manatee: Biology and Conservation. The University Press of Florida, Gainesville, USA.

Reynolds, III, J.E. (1981) Aspects of the social behaviour and herd structure of a semi-isolated colony of West Indian manatees, Trichechus manatus. Mammalia, 45, 431-452.
Self-Sullivan, C. \& Mignucci-Giannoni, A. (2008) Trichechus manatus ssp. manatus. In The IUCN Red List of Threatened Species 2008: e.T22105A9359161. Http://www.iucnredlist.org/ [accessed 29 October 2015].

Smethurst, D. \& Nietschmann, B. (1999) The distribution of manatees (Trichechus manatus) in the coastal waterways of Tortuguero, Costa Rica. Biological Conservation, 89, 267-274.

Stith, B.M., Reid, J.P., Langtimm, C.A., Swain, E.D., Doyle, T.J., SLONE, D.H. et al. (2011) Temperature inverted haloclines provide winter warm-water refugia for manatees in southwest Florida. Estuaries and Coasts, 34, 106-119.

\section{Biographical sketches}

Anmari Alvarez-Aleman is a research biologist and has led the manatee research programme in Cuba since 2007. JORGE ANGULO-VALDÉs's research interests include the management effectiveness of marine protected areas, conservation of natural resources, and bio-economics. Eddy García Alfonso is a conservation specialist. JAMES POWELL has worked for more than 40 years to conserve manatees and other threatened species around the world. His efforts have resulted in the designation of coastal protected areas in Florida, West Africa, Central America, and Cuba. Cynthia TAylor has more than 20 years' experience working with federal, state and private organizations on marine mammal research, rescue, management and conservation. Her research interests include the direct and indirect effects of human activities on threatened marine mammals and their habitats in regions of increased human use. 